\title{
Interpretations of the Spinoza's Monism (Part II)
}

\section{Luis F. A. Oliveira*, Marcio Augusto Damim Custódio}

\section{Abstract}

The purpose of this researche is to exhaust the attempts to bring plausibility for the Spinoza's claim: "Except God, no substance can be or be conceived" (EIP14). In this way, the Curley's (1988) view is exhausted by comparing the Spinoza's system with the well-knowing catesianism of his time. This analyse intends to show that Curley's argument it isin't enough to explain the Spinoza's metaphysics of substance as opposed, but not contraditory, to the cartesian dualism.

Key words: Monism, Dualism, Substance.

\section{Introduction}

The conclusion for existence of only one substance taked by Spinoza seems to be irreconcilable with the claims of Descartes' metaphysics. For Descartes, the world is constituted of various substance, of wich some are extense and some are thinkers. The concept that tooked Descartes for this claim is the logical independence of this two kinds of substance. However, the Spinoza's view is strongly diferent: there is only one substance and $t$ it is God, because God is the only necessary being, that is, the only existing thing that exists with no support of any other thing. This diference between Spinoza and Descartes is so radical that Curley's theory can't be sustained. For Curley the Spinoza's assertion is a kind of conclusion for the early development of cartesian system, and all theses of the dutch philosopher are derivates from the france one. The purpose of this work is to prove that both systems, of Spinoza and Descartes, are strictly opposites and there is no way to reconcile them.

\section{Results and Discussion}

Acording to Curley, the Spinoza's monism is a direct answer to the Descartes' philosophy, and the relation of proposition in Ethics I show this: P4 $\rightarrow$ P5 $\rightarrow$ P14.

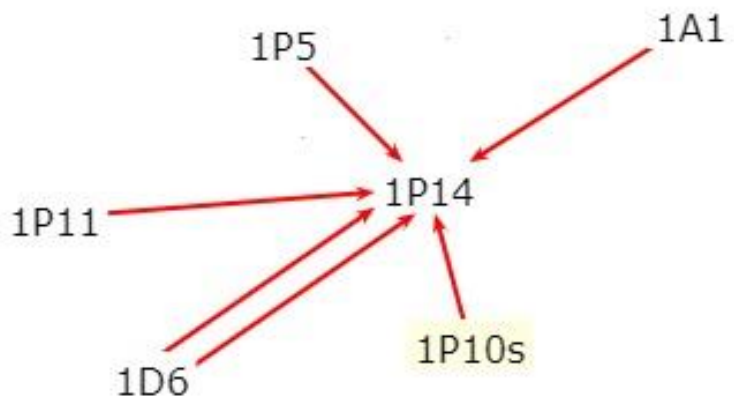

Image 1.

So for Spinoza's there is only one substance and this substance is God, the only thing that realy exists. All of this because God is the only thing that exists regardless. There are a lot of types of monism, but the Spinoza's monism is the most scrict one.

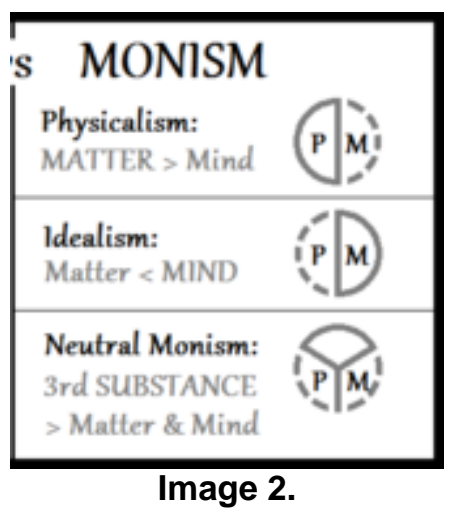

But Descartes' view is strongly diferent. For the author, the world is constituted of two sorts of substance, wich have the same importance. As we can see there are only minds and bodies. This is the cartesiam dualism.

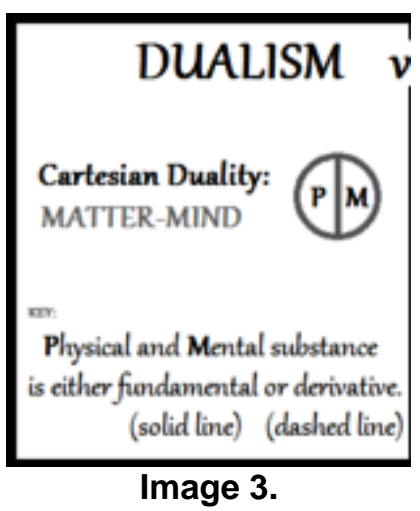

\section{Conclusions}

As we could, the Curley's wiew is unsustentable just for the reason that the metaphysical systems of Descartes and Spinoz are irreconcilable on this own roots.

\section{Acknowledgement}

I thank to PIBIC, CNPq, SAE and UNICAMP for funding this research; to Professor Márcio to for guiding me and believing in my potential; and to Cleyton and Diego, my good friends, who helped me in several moments.

<ethics.spinozism.org> (images 1 )

<Dustin Dewynne - Own work. 23 July 2012> (images 2 and 3).

GEBHARDT, C (Ed.). 1972. Spinoza opera. v. 1-4. Heidelberg: Car Winters.

CURLEY, Edwin; CURLEY, Edwin M. Behind the geometrical method: A reading of Spinoza's Ethics. Princeton University Press, 1988. 